\title{
GM-CSF up-regulates the expression of CCL2 by T lymphocytes in mammary tumor-bearing mice
}

\author{
JENNIFER L. OWEN ${ }^{1}$, MARTA TORROELLA-KOURI ${ }^{2}$, \\ MARY E. HANDEL-FERNANDEZ ${ }^{2}$ and VIJAYA IRAGAVARAPU-CHARYULU ${ }^{1}$ \\ ${ }^{1}$ Department of Basic Biomedical Sciences, Florida Atlantic University, Boca Raton, FL 33431; \\ ${ }^{2}$ Department of Microbiology and Immunology, University of Miami Miller School of Medicine, Miami, FL 33136, USA
}

Received January 16, 2007; Accepted February 23, 2007

\begin{abstract}
MCP-1/CCL2 (monocyte chemoattractant protein$1 / \mathrm{CC}$ chemokine ligand 2 ) is a $\mathrm{B}$ or $\mathrm{CC}$ chemokine that is expressed by a variety of cell types, including fibroblasts, endothelial, smooth muscle, and glial cells. In addition, cells involved in immunity, such as monocytes/macrophages, neutrophils, and eosinophils have also been shown to express this chemoattractant. Using a murine model of the D1DMBA-3 mammary adenocarcinoma, we demonstrated the unique production of CCL2 by splenic T lymphocytes from tumor-bearing animals. Because this tumor produces GM-CSF, and this factor is also up-regulated in the B lymphocytes of tumor-bearing mice, we looked at the ability of GM-CSF to induce CCL2 production by T cells. Treatment of normal and tumor bearers' T cells with GM-CSF resulted in an increased secretion of this chemokine. This up-regulation was seen with or without stimulation by Concanavalin A, although these treatments were additive in their effects. The induction of CCL2 was studied at the molecular level by analyzing the effect(s) of a variety of physiological and pharmacological agents on cultured $\mathrm{T}$ cells. These results suggest that the tumor-derived factor GM-CSF activates various signaling pathways within splenic $\mathrm{T}$ cells to upregulate CCL2 expression.
\end{abstract}

\section{Introduction}

Cytokines and chemokines serve as important mediators of the functional responses of leukocytes. An effective antitumor response requires the recruitment of effector cells such as $\mathrm{T}$ cells and macrophages to the site of the neoplasm and

Correspondence to: Dr Vijaya Iragavarapu-Charyulu, Florida Atlantic University, Charles E. Schmidt College of Biomedical Science, 777 Glades Road, P.O. Box 3091, Boca Raton, FL 334310991, USA

E-mail: iragavar@fau.edu

Key words: GM-CSF, CCL2, T lymphocytes, mammary tumor the appropriate activation of these cells. Chemokines are a group of inducible, proinflammatory cytokines that interact with leukocytes and recruit them into the tumor. Clinically, elevated levels of chemokines have been found in a variety of inflammatory diseases including cancer (1). The prototype $\mathrm{CC}$ chemokine is a monocyte chemoattractant protein-1 (MCP-1/CCL2) that was first identified as a potent chemotaxin for monocytes (2) and is also a chemotactic for activated $\mathrm{T}$ lymphocytes, natural killer cells, and basophils (3-5). This chemokine is synthesized by a variety of cell types in response to various stimuli including cytokines.

We previously reported that the D1-DMBA-3 tumor secretes factors that directly or indirectly affect leukocytes resulting in immunosuppression and dysregulated cytokine expression (6). Elevated levels of GM-CSF and CCL2 are found in the sera of mammary tumor-bearing mice relative to normal control mice, and our studies indicate that DA-3 cells, a tumor cell line derived from the D1-DMBA-3 tumor, secrete GM-CSF (7). Although there are several reports of tumors producing CCL2, this protein is not detected in the supernatants of DA-3 cells. We have shown that CCL2 is induced in the T lymphocytes by tumor-derived GM-CSF (8). The effects of GM-CSF are triggered by the binding of the ligand to its cell surface receptor leading to the phosphorylation of molecules involved in signaling. Several signaling pathways have been identified downstream of GMCSF receptors in several cell types including myeloid cells $(9,10)$, monocytes $(11)$, neutrophils (12), microglial cells (13) and endothelial cells (14). GM-CSF has been shown to activate the phosphatidylinositol-3 kinase/Akt (PI-3/Akt), Janus kinase/signal transducer and activator of transcription (JAK/STAT) and Ras/extracellular signal-related kinase/ mitogen-activated protein kinase (Ras/ERK/MAPK) cascades to different extents depending on cell type $(10,15,16)$. It is known that parallel signaling pathways are activated during cytokine gene induction. GM-CSF has been reported to also activate PI-3 kinase, JAK/STAT and Ras-Raf-ERK signaling pathways in neutrophils (17). However, the signaling events involved in GM-CSF activation of $\mathrm{T}$ lymphocytes need further elucidation.

Martin et al (18) have shown that the induction of CCL2 protein in endothelial cells by TNF- $\alpha$ and IL- $1 \beta$ is dependent on the binding of the nuclear factor of $\kappa \mathrm{B}(\mathrm{NF}-\kappa \mathrm{B})$ to its 
consensus site. Thus, the role of $\mathrm{NF}-\kappa \mathrm{B}$ in the induction of CCL2 by $\mathrm{T}$ lymphocytes of mammary tumor-bearing mice was evaluated. The ubiquitous and evolutionarily conserved $\mathrm{NF}-\kappa \mathrm{B}$ family of proteins is involved in the transcriptional regulation of a number of cellular genes. The NF-kB family of proteins is comprised of five members: p65 (RelA), RelB, c-Rel, NF-кB1 (which occurs as a precursor p105 and its processed product $\mathrm{p} 50$ ) and NF- $\mathrm{KB} 2$ (which occurs as a precursor $\mathrm{p} 100$ and its product $\mathrm{p} 52$ ). In most normal cells, the $\mathrm{Rel} / \mathrm{NF}-\kappa \mathrm{B}$ dimers are retained in the cytoplasm as an inactive complex through the direct binding of an I $\mathrm{KB}$ inhibitor. On cytokine activation, degradation of $\mathrm{I} \kappa \mathrm{B}$ and subsequent nuclear translocation of active Rel/NF-кB takes place (19-21). Our results indicated that p50 homodimer and p50-c-Rel heterodimer NF- $\mathrm{KB}$ transcription factors were involved in the activation pathway leading to CCL2 production. In this study, inhibitors of signaling molecules were used to determine the signaling pathways involved in the GM-CSF induction of CCL2 in T lymphocytes.

\section{Materials and methods}

Mice and cell lines. BALB/c mice used in these studies were 8-12 weeks of age and bred in the animal facility at the University of Miami. Animal care and use was according to the guidelines of the National Institute of Health. The D1DMBA-3 tumor, syngeneic to BALB/c mice, is a transplantable mammary adenocarcinoma derived from a nonviral, noncarcinogen-induced preneoplastic nodule after treatment with 7,12-dimethylbenzanthracene (22). The D1DMBA-3 tumor is immunogenic to the host of origin, nonmetastatic to the spleen, but metastases to the lung and bone marrow occur. The DA-3 mammary tumor cell line was derived from the D1-DMBA-3 tumor and maintained in DMEM/high glucose, $10 \%$ characterized heat-inactivated FCS (Hyclone Laboratories, Logan, UT), $100 \mathrm{U} / \mathrm{ml}$ of penicillin, $100 \mu \mathrm{g} / \mathrm{ml}$ of streptomycin, and OPI media supplement (Sigma Chemical Co., St. Louis, MO). Tumors were implanted in BALB/c mice by subcutaneous injection of $1 \times 10^{6}$ tumor cells resulting in a measurable tumor 7-10 days post implantation.

Purification of splenic $T$ cells. Spleens were compressed in Teflon tissue homogenizers and the resulting single-cell suspension was pelleted at $300 \mathrm{x} \mathrm{g}$, subjected to hypotonic shock for red cell removal, washed and counted. Macrophages were removed from the cell suspension by plastic adherence in pre-warmed RPMI-1640, 5\% FCS at $37^{\circ} \mathrm{C}$ for $1 \mathrm{~h}$ in a $\mathrm{CO}_{2}$ incubator. The non-adherent $\mathrm{T}$ lymphocytes were purified on nylon wool columns according to the method of Julius et al (23) and by positive selection using the Macs Magnetic separation system (Miltenyi Biotec, Auburn, CA) according to the manufacturer's instructions. Briefly, single-cell suspensions in cold PEB buffer (PBS supplemented with $2 \mathrm{mM}$ EDTA and $0.5 \%$ BSA) were incubated with supermagnetic microbeads conjugated to anti-mouse CD90 (Thy1.2) mAb at $4^{\circ} \mathrm{C}$ for $15 \mathrm{~min}$. Cells were washed twice and loaded onto the magnetic separation columns. The columns were washed three times with cold PEB buffer, and the positively selected Thy $1.2^{+}$cells were then eluted. After purification, the cells were routinely $>95 \%$ viable, as assessed by trypan blue exclusion. FACS analysis using a Becton Dickinson LSR analyzer and anti-mouse FITC-CD90 antibodies (BD Biosciences Pharmingen, San Diego, CA) confirmed the populations to be $\geq 93 \%$ Thy $1.2+\mathrm{T}$ lymphocytes.

Cell culture. After purification, splenic T cells cultured for ELISAs were re-suspended in complete media consisting of RPMI-1640, 10\% FCS, $100 \mathrm{U} / \mathrm{ml}$ of penicillin, $100 \mu \mathrm{g} / \mathrm{ml}$ of streptomycin, and $50 \mathrm{mM}$ 2-ME and cultured for various time points. At the end of the incubation period, the supernatants were removed and stored at $-80^{\circ} \mathrm{C}$ until use. The following reagents were used in experiments as noted: Concanavalin A and $\mathrm{N} \alpha$-p-Tosyl- ${ }_{\mathrm{L}}$-Lysine Chloro-methyl ketone (TLCK) (Sigma Chemical Co.), recombinant murine GM-CSF (PeproTech, Rocky Hill, NJ), wortmannin, staurosporine, and PD 98059 (Calbiochem, San Diego, CA).

\section{RNA analysis}

$R T-P C R$. Total RNA was isolated from purified T cells from normal and four-week-old tumor-bearing mice using TriReagent (Molecular Research Center, Cincinnati, OH). One microgram of total RNA was reverse transcribed using a Primus thermocycler (MWG Biotech, High Point, NC) and the GeneAmp RNA PCR kit (Applied Biosystems, Foster City, CA) with Oligo $\mathrm{d}(\mathrm{T})_{16}$ primers, according to the manufacturer's instructions. The reaction was incubated for $60 \mathrm{~min}$ at $42^{\circ} \mathrm{C}$, followed by inactivation of the MuLV reverse transcriptase at $99^{\circ} \mathrm{C}$ for $5 \mathrm{~min}$. The cDNA products obtained were subjected to PCR for 35 cycles, after which $15 \mu 1$ of the amplified DNA fragments were electrophoresed on a $1.4 \%$ agarose gel stained with ethidium bromide and visualized by UV transillumination. The gels were analyzed with Scion Image $\beta 4.02$ densitometry software (Scion, Frederick, MD) and normalized with $\beta$-actin band intensity. The PCR for GM-CSFR- $\alpha$ amplification was carried out by incubating the samples at $94^{\circ} \mathrm{C}$ for $10 \mathrm{~min}$, followed by 35 cycles of $95^{\circ} \mathrm{C}$ for $30 \mathrm{sec}, 59^{\circ} \mathrm{C}$ for $30 \mathrm{sec}$, and $72^{\circ} \mathrm{C}$ for $30 \mathrm{sec}$, with a final extension for $10 \mathrm{~min}$ at $72^{\circ} \mathrm{C}$. The primers were as follows: murine GM-CSFR- $\alpha$ sense, 5'-AACGTGACT GACAGGAAGG-3'; antisense, 5'-TGTGTGTGCTGGCT GTTAAGG-3' (24); and murine $\beta$-actin sense, 5'-TCTGG CACCACACCTTCTAC-3'; antisense, 5'-GAAGGAAGGCT GGAAGAGTG-3' (25).

Gene expression array analysis. The relative mRNA expression of the mouse $\mathrm{NF}-\kappa \mathrm{B}$ signaling pathway was analyzed with the chemiluminescent GEArray Q Series (SuperArray Inc., Bethesda, MD) according to the manufacturer's protocol. Briefly, total RNA was isolated and $5 \mu \mathrm{g}$ from unstimulated or GM-CSF-stimulated T lymphocytes of normal and tumor-bearing mice was reverse transcribed into cDNA with Moloney murine leukemia virus reverse transcriptase (Promega, Madison, WI) and amplified in the presence of biotin-16-dUTP (Roche, Indianapolis, IN). The resulting cDNA probes were hybridized to cDNA fragments that were spotted on the GEArray nylon membranes. The relative expression level of each gene was analyzed by densitometry using Scion program and the densities were normalized with $\beta$-actin. 
Cytokine ELISA. The amounts of CCL2 present in the supernatants of cultured T lymphocytes were measured by OptEIA $^{\mathrm{TM}}$ ELISAs (BD Biosciences Pharmingen), according to the manufacturer's instructions. Absorbance at $450 \mathrm{~nm}$ was read on a Tecan SLT Rainbow reader (Labinstruments, Research Triangle Park, NC) and the OD values of the samples were converted to picograms against a standard curve of known quantities of CCL2.

Nuclear extracts. Nuclear extracts were prepared by the method of Schreiber et al (26). T cells $\left(6 \times 10^{6}\right)$ were cultured in 6-well tissue culture plates and incubated overnight in the presence of GM-CSF. Cells were washed twice with PBS, then treated with cold buffer A (10 mM HEPES, pH 7.9, $10 \mathrm{mM} \mathrm{KCl}, 0.1 \mathrm{mM}$ EDTA, $0.1 \mathrm{mM}$ EGTA, $1 \mathrm{mM}$ DTT, $0.5 \mathrm{mM}$ PMSF, $0.1 \mathrm{mM}$ antipain, $10 \mu \mathrm{g} / \mathrm{ml}$ aprotinin, $0.1 \mathrm{mM}$ chymostatin, $0.1 \mathrm{mM}$ leupeptin, and $1 \mathrm{mM}$ pepstatin). The cells were left to swell on ice for $15 \mathrm{~min}$, after which $25 \mu \mathrm{l}$ of $10 \%$ NP-40 was added and vortexed for $10 \mathrm{sec}$. Nuclei were removed from cytosol by centrifugation at $14,000 \mathrm{rpm}$ for $30 \mathrm{sec}$. The supernatants were removed and the nuclear pellets re-suspended in $50 \mu 1$ of ice-cold buffer B (20 mM HEPES, pH 7.9, 0.4 M NaCl, 1 mM EDTA, 1 mM DTT, 1 mM PMSF, $0.1 \mathrm{mM}$ antipain, $10 \mu \mathrm{g} / \mathrm{ml}$ aprotinin, $0.1 \mathrm{mM}$ chymostatin, $0.1 \mathrm{mM}$ leupeptin, and $1 \mathrm{mM}$ pepstatin) and the tubes were rocked vigorously at $4^{\circ} \mathrm{C}$ for $15 \mathrm{~min}$. The extracts were centrifuged at $14,000 \mathrm{rpm}$ for $5 \mathrm{~min}$ at $4^{\circ} \mathrm{C}$, and the supernatants were stored at $-70^{\circ} \mathrm{C}$. Protein concentration was measured by a previously described modification of the method of Lowry et al (27) using the Sigma protein determination kit (St. Louis, MO).

Electrophoretic mobility shift assay (EMSA). Nuclear extracts (5 $\mu \mathrm{g} / \mathrm{sample})$ were incubated in a $20-\mu 1$ volume with $1 \mathrm{X}$ binding buffer $(10 \mathrm{mM}$ Tris- $\mathrm{HCl}, \mathrm{pH} 7.5,50 \mathrm{mM} \mathrm{NaCl}$, and $0.5 \mathrm{mM}$ DTT), $10 \%$ glycerol, $0.05 \% \mathrm{NP}-40,1 \mu \mathrm{g}$ of poly(dI$\mathrm{dC}$ )-poly(dI-dC) (Pharmacia, Piscataway, NJ) on ice for $10 \mathrm{~min}$ (164) before addition of ${ }^{32} \mathrm{P}$-labeled target DNA (1 ng), corresponding to sequences in the promoter to be analyzed. To ensure specificity, a 50X concentration (50 ng) of unlabeled competitor DNA was included in the sample prior to the addition of the radiolabeled probe. After the completion of the binding reaction, $2 \mu 1$ of $10 \mathrm{X}$ loading buffer $(250 \mathrm{mM}$ Tris- $\mathrm{HCl}, \mathrm{pH} 7.5,0.2 \%$ bromophenol blue, $0.2 \%$ xylene cyanol, and $40 \%$ glycerol) was added and samples were electrophoresed at $4^{\circ} \mathrm{C}$ through a $5 \%$ polyacrylamide gel in $0.5 \mathrm{X}$ TBE buffer $(0.045 \mathrm{M}$ Tris-borate, $0.001 \mathrm{M}$ EDTA, $\mathrm{pH}$ 8.0) which had been pre-run at $10 \mathrm{~V} / \mathrm{cm}$ for $2 \mathrm{~h}$ prior to the sample loading. The gels were dried and visualized by autoradiography.

Supershift assay. In some EMSAs, the procedure was followed as detailed above except that $2 \mu \mathrm{g}$ of affinitypurified rabbit polyclonal antibodies against various transcription factors (Santa Cruz Biotechnology, Santa Cruz, CA) was included in the binding reaction. Antibodies were blocked by the addition of excess specific peptides.

Statistical analysis. Data were expressed as the mean \pm SD. Statistical significance was determined using the two-tailed
Students's t-test. Values of $\mathrm{p}<0.05$ were considered statistically significant.

\section{Results}

Recombinant GM-CSF induces the secretion of CCL2 in splenic $T$ cells. To analyze the influence of mammary tumorderived and/or -induced factors on the enhanced levels of CCL2 in T cells from tumor bearers, we treated normal and tumor bearers' $\mathrm{T}$ lymphocytes with titrations of previously identified factors, either alone or in combination including TNF- $\alpha$, PGE $_{2}$, VEGF, IL-6 and phosphatidyl serine (data not shown). GM-CSF proved to be a tumor-derived factor that induces the secretion of CCL2 in T lymphocytes. Thus, splenic $\mathrm{T}$ cells from normal and tumor-bearing animals were purified and treated with a titration of recombinant murine GM-CSF (rmGM-CSF) (Fig. 1A). Stimulation with recombinant GM-CSF at concentrations similar to those found in tumor-bearers' sera or the tumor cell cultures $(7,28)$ induced the secretion of CCL2 in T lymphocytes. DA-3 tumor cells constitutively secrete $\sim 200-300 \mathrm{pg} / \mathrm{ml}$ of GM-CSF, and $2000 \mathrm{pg} / \mathrm{ml}$ of GM-CSF has been measured in the sera of mammary tumor bearers $(29,30)$. The stimulation of tumor bearers' $\mathrm{T}$ cells with as little as $100 \mathrm{pg} / \mathrm{ml}$ GM-CSF resulted in the secretion of $248 \pm 75 \mathrm{pg} / \mathrm{ml}$ CCL2. The amount of CCL2 produced in GM-CSF-stimulated cultures of normal T cells ranged from $24 \pm 7.1$ to $35.4 \pm 7.5 \mathrm{pg} / \mathrm{ml}$, whereas the CCL2 produced by tumor bearers' T cells was from $248 \pm 74.8$ to $707.2 \pm 126.4 \mathrm{pg} / \mathrm{ml}$. As well as being dose dependent, the induction of CCL2 with GM-CSF treatment acted in a timedependent fashion (Fig. 1B). Maximum secretion of CCL2 was seen when the $\mathrm{T}$ cells were stimulated overnight with recombinant GM-CSF and/or the plant lectin, Concanavalin A. Furthermore, the two stimulations acted additively in the induction of the chemokine by the $\mathrm{T}$ lymphocytes. The biologic activity of cytokines is mediated by the binding of the ligand to their specific receptors. The GM-CSF receptor complex consists of a low-affinity binding $\alpha$-subunit and the common $\beta$-subunit of the cytokine receptor family that does not bind GM-CSF itself, but forms a high-affinity receptor in combination with the $\alpha$-subunit and is responsible for signal transduction (31). We therefore analyzed the expression of the GM-CSFR- $\alpha$ subunit in the T cells of normal and tumor bearers by RT-PCR. T cells from four-week-old tumorbearing mice expressed higher levels of GM-CSFR- $\alpha$ compared to the normal mice (Fig. 1C). Furthermore, T cells isolated from mammary tumor bearers express higher levels of both GM-CSFR $\alpha$ and GM-CSFRß receptor proteins than do $\mathrm{T}$ cells from normal control mice (8).

Molecular pathways involved in the GM-CSF-induced secretion of CCL2. Pro-inflammatory cytokines and chemokines are often expressed in response to $\mathrm{NF}-\kappa \mathrm{B}$ activation (32-34) and induced expression of CCL2 does indeed require activation of this family of transcription factors in human glioblastoma and human fibrosarcoma cells stimulated with TNF- $\alpha$ (35). A gene array of molecules involved in NF-кBmediated signal transduction was used to gain insight into which molecules may be affected in the GM-CSF-induced CCL2 production (Fig. 2A). The constitutively and GM- 
A.

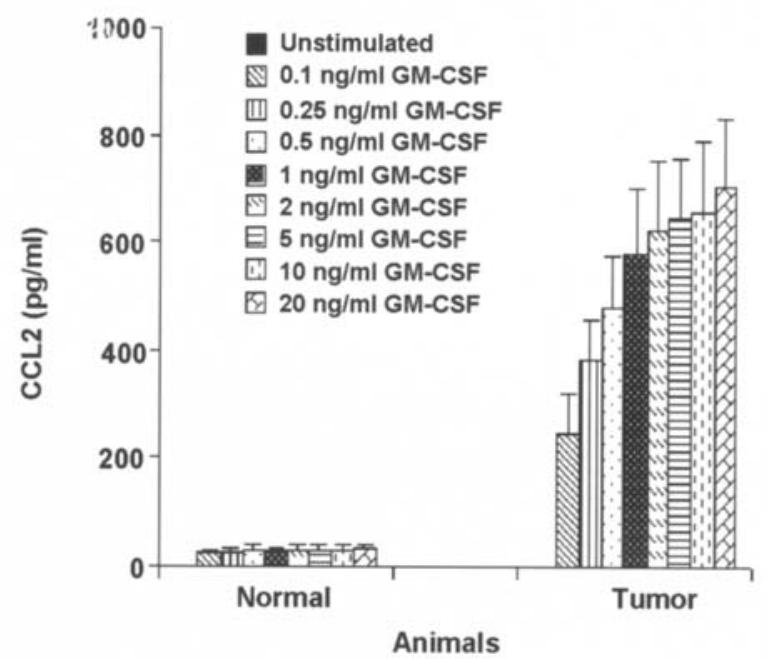

B.

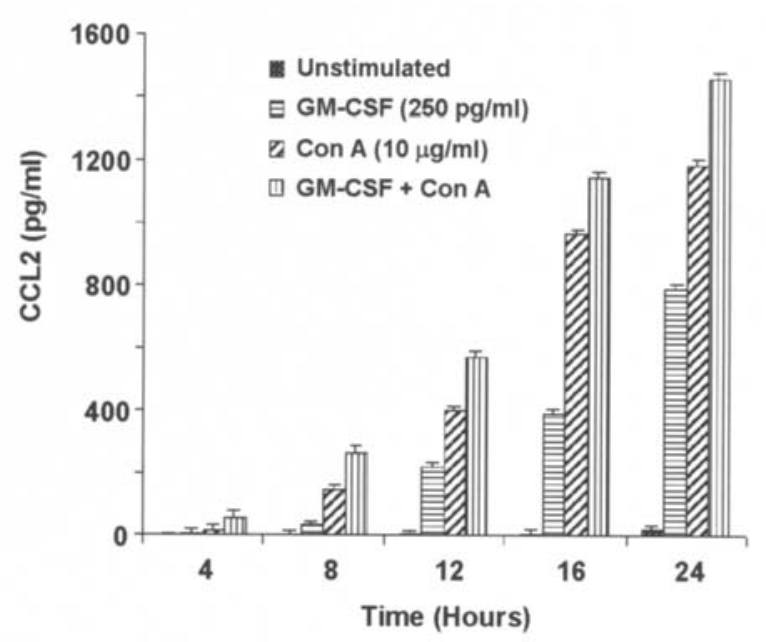

C.
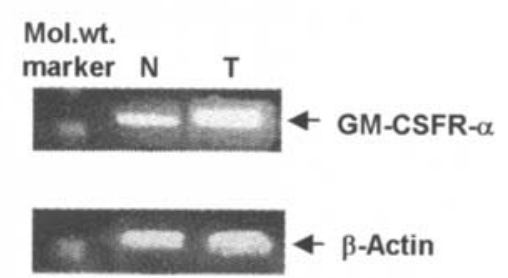

Figure 1. GM-CSF induces CCL2 production in splenic T cells in a dosedependent and time-dependent fashion and GM-CSFR- $\alpha$ is expressed by $\mathrm{T}$ lymphocytes. (A) Purified splenic $\mathrm{T}$ cells from normal and 4-week-old tumor-bearing mice were cultured overnight with increasing concentrations of recombinant GM-CSF. Cell-free supernatants were collected and assayed by ELISA. Data are representative of three independent experiments with at least 5 mice per group. (B) Purified splenic T cells from 4-week-old tumorbearing mice were cultured for various time points with GM-CSF and/or Concanavalin A. Cell-free supernatants were collected and assayed by ELISA. Data are representative of three independent experiments with at least 5 mice per group. (C) Purified splenic T cells from normal and 4-weekold tumor bearers were analyzed for GM-CSF receptor- $\alpha$ expression by semi-quantitative RT-PCR as described in Materials and methods.

CSF-induced expression of genes in the Rel/NF-kB family and various signal transduction kinases and transcription factors were analyzed using this array. The constitutive expression of genes encoding cyclic AMP-responsive elements (CREB-2 and CREB), Elk 3 and the basic helixloop-helix/leucine zipper protein Max were similar in $\mathrm{T}$ lymphocytes from both normal and tumor-bearing mice (Fig. 2B). Interestingly, there was increased expression of the CREB-2 and CREB, Elk1, Elk3, and Max genes induced by GM-CSF in normal $\mathrm{T}$ cells compared to tumor bearers' $\mathrm{T}$ lymphocytes. The constitutive expression of the Raf1 gene was higher in the T cells of tumor-bearing mice but in contrast, the GM-CSF-induced expression of this gene was higher in the $\mathrm{T}$ cells of normal mice. Similar patterns of gene expression were observed in the NF- $\mathrm{KB}$ family of transcription factors induced by GM-CSF (Fig. 2C). GM-CSF induced higher levels of mRNA expression of IKK- $\beta$, NF-кB1, NF-кB2, iкB $\alpha$, Nfkbie, c-Rel, and RelA (p65) in the T cells of normal mice but there were no significant differences in the expression of the IKK- $\gamma$, NF-kbIL1, NFкBIL2 and I-Rel genes from the two types of mice. The constitutive expression

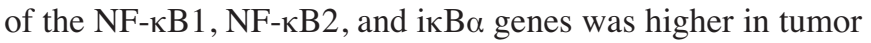
bearers' T cells, while basal levels of Nfkbie, NFkbIL1 and RelA (p65) expression were higher in T cells from normal mice (Fig. 2C). Although GM-CSF was found to increase the mRNA expression of key signaling molecules such as Map2k1, Map2k4, MEKK1, MEKK2, Map3k14, Mapk14, Mapk8 and Mapk9 in T lymphocytes of both normal and tumor-bearing mice (Fig. 2D), the levels of mRNA induced by GM-CSF were higher in the $\mathrm{T}$ cells of normal mice compared to those of tumor bearers' $\mathrm{T}$ cells. In contrast, the constitutive expression of Map2k1, Map2k4, Map2k7, Mapk14 and ERK was higher in tumor bearers' T lymphocytes, while the mRNA expression of MEKK1 and Tbk 1 was higher in T cells from normal mice. (Fig. 2D).

$\mathrm{NF}-\kappa \mathrm{B}$ plays a crucial role in many inflammatory diseases such as arthritis, asthma and atherosclerosis, as well as cancer. Various members of the NF- $\mathrm{kB} /$ Rel family have been shown to regulate many genes involved in immune and inflammatory responses (36-39). Since the results from our NF- $\kappa$ B-mediated signal transduction gene array studies indicated that multiple genes are affected by GM-CSF in T cells, identification of the nuclear factors that play a role in the expression of CCL2 by tumor bearers' T lymphocytes was investigated. To determine which of the nuclear factors played a role in tumor bearers' $\mathrm{T}$ lymphocytes, electrophoretic mobility shift assays were performed. Using an NF- $\mathrm{kB}-$ specific probe corresponding to the murine CCL2 promoter, EMSAs of the nuclear proteins from normal and tumor bearers' T cells stimulated with GM-CSF revealed a pattern of higher intensity bands from the tumor bearers' nuclear extracts, indicating a greater amount of NF- $\mathrm{kB}$ transcription factors bound to the recognition motif (Fig. 3A). The specificity of the DNA-bound complexes was determined by cold competition with excess NF-kB or with the irrelevant oligonucleotide Oct-1. These results showed that nuclear extracts from splenic $\mathrm{T}$ cells were specific for NF- $\mathrm{\kappa B}$ because they could be competed by an excess of an unlabeled NF-kB sequence but not by an oligonucleotide containing an irrelevant Oct-1 binding motif (Fig. 3A). To determine which 
A.

\section{Normal \\ Unstimulated}

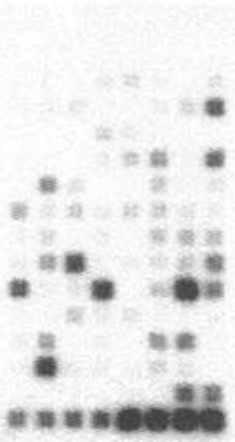

Tumor

Unstimulated

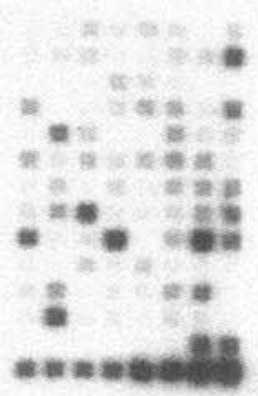

Normal

+ GM-CSF

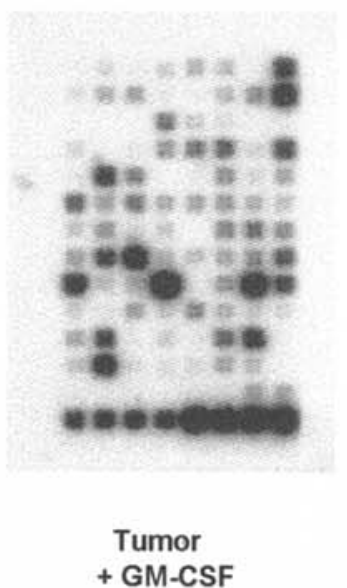

+ GM-CSF

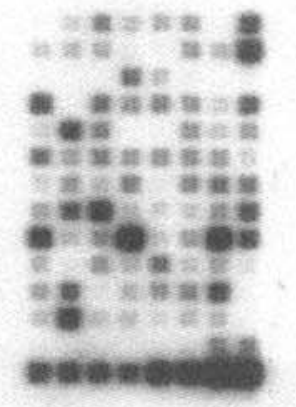

B.

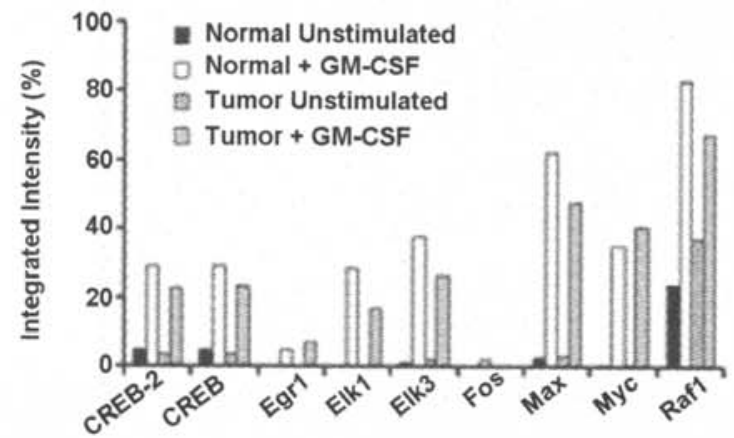

C.

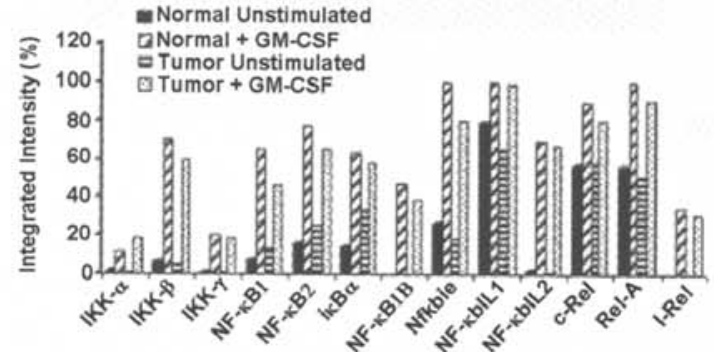

D.

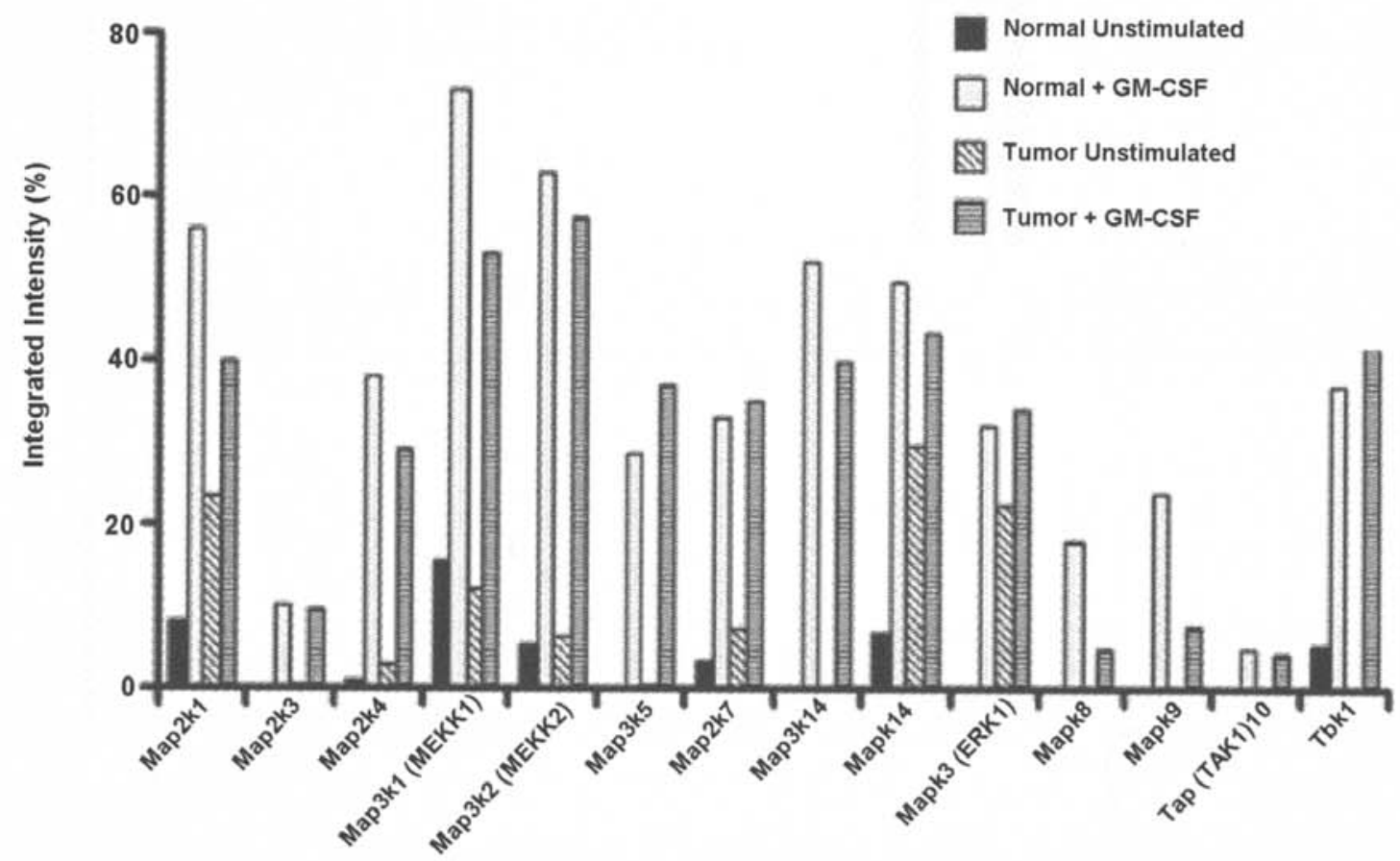

Figure 2. Murine NF-kB mediated signaling pathway gene array. (A) Representative gene expression array analysis of splenic $\mathrm{T}$ cell $\mathrm{mRNA}$ from normal and tumor-bearing animals. $B$-actin mRNA expression is shown in the last two tetra-spots and was used to normalize the expression results. (B) Integrated intensity of transcription factors normalized to $\beta$-actin. (C) Integrated intensity of Rel/NF-кB/IкB family transcription factors normalized to $\beta$-actin. (D) Integrated intensity of signal transduction kinases normalized to $\beta$-actin. 
A.

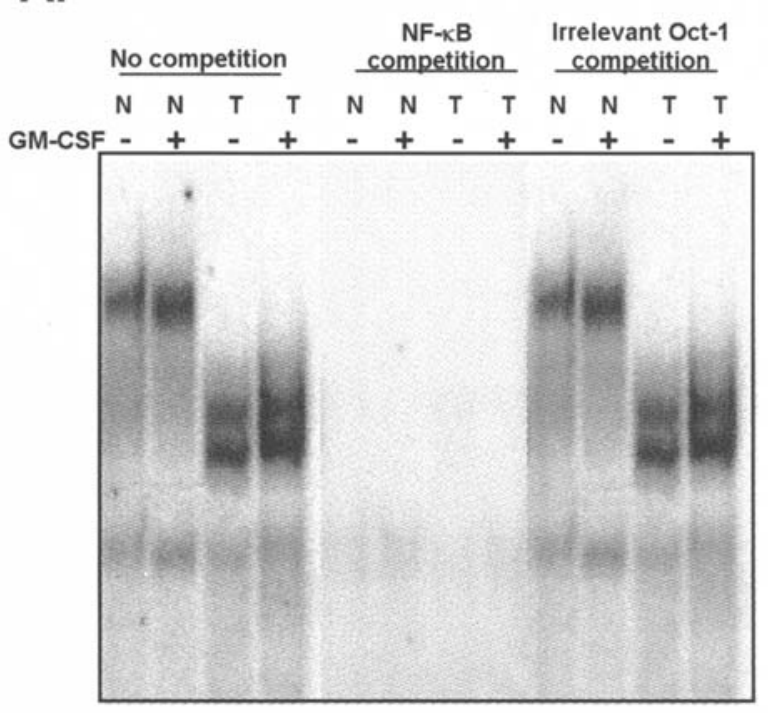

B.

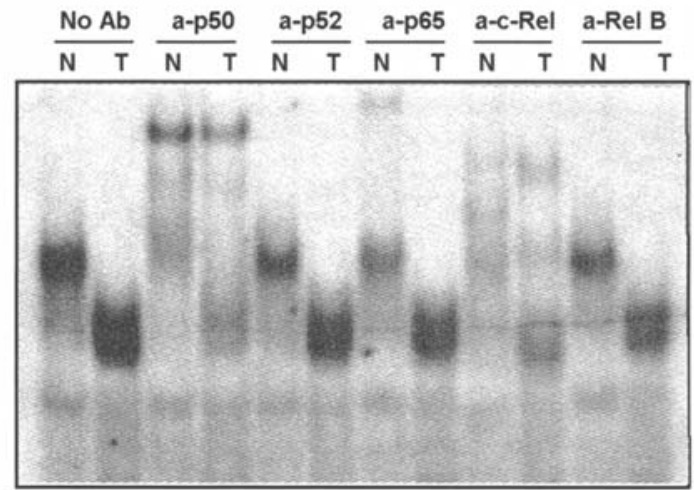

Figure 3. DNA binding affinity of NF- $\kappa$ B to the NF- $\kappa \mathrm{B}$ recognition motif in the nuclear extracts of normal and tumor bearers' $\mathrm{T}$ cells. (A) Activation of $\mathrm{NF}-\kappa \mathrm{B}$ binding was analyzed by EMSA using a radioactively labeled oligonucleotide corresponding to the NF- $\mathrm{\kappa B}$ recognition motif and nuclear extracts from normal (N) and tumor bearers' (T) T cells cultured for $2 \mathrm{~h}$. (B) Specificity of the DNA-bound complexes was determined by supershift analysis. Specific anti-NF-кB transcription factor Abs were included in the binding reactions. These gels are representative of at least four independent experiments.

nuclear factors contributed to the altered binding pattern seen, a supershift experiment was performed in which antibodies to known $\mathrm{NF}-\kappa \mathrm{B}$ family members were added to the DNA binding reaction (Fig. 3B). Anti-p50, -p65, and -cRel antibodies efficiently 'supershifted' the DNA-binding complexes with a concomitant reduction in the intensity of the shifted band, indicating that these transcription factors were involved in the expression of CCL2 in splenic T cells. While p50 and c-Rel were involved in the binding of the NF$\kappa \mathrm{B}$ promoter of normal and tumor bearers' $\mathrm{T}$ cells, p50 was highly involved, as evidenced by the more dramatic shifts. In contrast, RelA (p65) bound only to the CCL2 promoter in the nuclear extracts from normal $\mathrm{T}$ cells. The binding of these higher molecular weight transcription factors to the CCL2 promoter in normal $\mathrm{T}$ cells partly explained the retarded migration of nuclear extracts from normal $\mathrm{T}$ lymphocytes

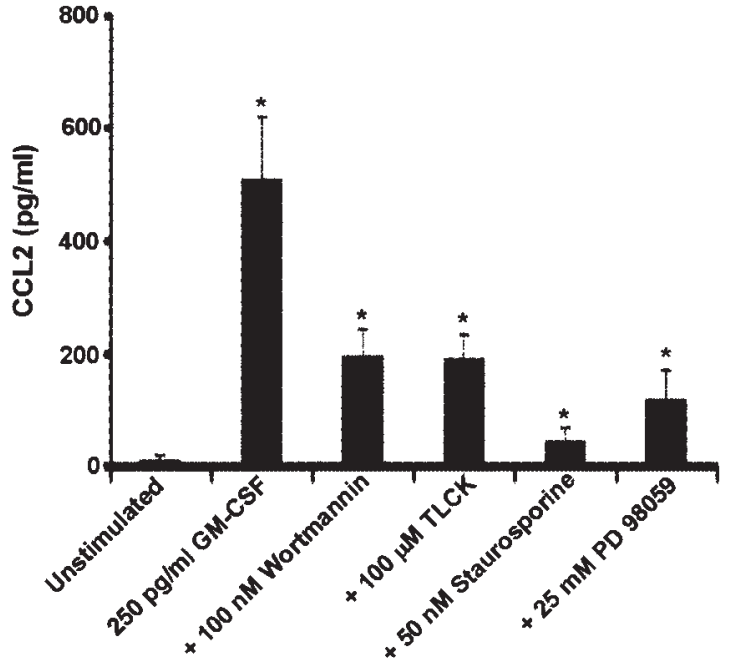

Figure 4. Effect of molecular inhibitors on GM-CSF-induced CCL2 secretion by tumor bearers' T cells. Purified splenic T cells from 4-week-old tumor-bearing mice were cultured overnight with $250 \mathrm{pg} / \mathrm{ml}$ recombinant

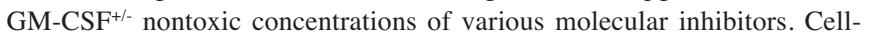
free supernatants were collected and assayed by ELISA. These data are representative of four independent experiments. *Significant differences $(\mathrm{p}<0.05)$ between $\mathrm{T}$ cells treated with GM-CSF alone and with the addition of inhibitors to the culture media.

compared to those of tumor bearers. The predominant transcription factor complex involved in the NF- $\kappa \mathrm{B}$ promoter in tumor bearer's T cells was p50/p50 homodimers but p50-cRel heterodimers also appeared to be involved.

The induction of cytokine/chemokine genes involves multiple signaling pathways some of which merge at the level of NF-кB. Upstream of NF-кB, MAPK, PI3 kinase and $\mathrm{PKC}$ have been shown to be activated in neutrophils in response to GM-CSF $(17,40,41)$. In other studies, GM-CSF has been shown to activate Akt, a downstream substrate of PI-3K (15) and the MAP kinase, ERK (42). Thus, pharmacologic inhibitors were used to dissect the signaling pathways involved in the GM-CSF-mediated secretion of CCL2 in T lymphocytes. The inclusion of staurosporine, a protein kinase inhibitor; wortmannin, an inhibitor of PI-3K; N $\alpha$-p-Tosyl- ${ }_{\mathrm{L}^{-}}$ Lysine Chloro-methyl ketone (TLCK), an inhibitor of NF-kB; and PD 98059, an inhibitor of the MAPK/ERK pathway in T cell cultures resulted in a down-regulation of CCL2 secretion in the GM-CSF-stimulated T cells from tumor-bearing mice (Fig. 4). T lymphocytes from four-week-old tumor-bearing mice constitutively secreted $\sim 10 \mathrm{pg} / \mathrm{ml} \mathrm{CCL} 2$, and $\sim 500 \mathrm{pg}$ / $\mathrm{ml}$ of CCL2 was secreted by GM-CSF-stimulated T lymphocytes. In contrast, T cells cultured in the presence of pharmacologic inhibitors staurosporine, wortmannin, TLCK and PD 98059 secreted 194, 188, 40 and $110 \mathrm{pg} / \mathrm{ml}$ of CCL2, respectively. Viability was not affected by these concentrations of the inhibitors, as assayed by trypan blue exclusion.

\section{Discussion}

We previously observed that mammary tumor-derived factors, including GM-CSF induce CCL2 expression in the T lymphocytes of tumor-bearing animals (8). In the same study, 
we showed that exposure of T cells to CCL2 resulted in decreased production of interferon- $\gamma$, a key cytokine critical during tumor development for the immunologic defenses of the host. The present study demonstrated that this secretion of CCL2 by GM-CSF-stimulated T lymphocytes was both time and dose dependent. Little is known about the molecular pathways that are activated following the binding of GMCSF to its receptor in primary T lymphocytes. Notably, GMCSFR- $\alpha$ is up-regulated in the tumor-bearers' $\mathrm{T}$ lymphocytes which favors the triggering of various signaling pathways. Thus, the current study analyzed the signaling pathways involved in the GM-CSF-induced CCL2 secretion by T cells.

Signaling pathways and the ensuing activation of specific genes involved in response to GM-CSF vary depending upon the cell type. For example, the ERK and the Jak2/STAT pathways are activated in human neutrophils $(12,40)$ in response to GM-CSF, however the NF- $\mathrm{KB}$ pathway is not activated by similar treatment (43). In contrast, elevated levels of NF- $\mathrm{BB}$ signaling components were observed in monocytes pre-treated with GM-CSF (11). Gene array studies were performed to gain insight into the molecular pathways involved in the induction of CCL2 in T cells stimulated with GM-CSF. In this study, we found that GM-CSF induced the increased mRNA expression of multiple factors including NF- $\kappa \mathrm{B}, \mathrm{CREB}$, and Raf1 transcription factors and the MAPK signal transduction proteins.

The NF- $\mathrm{NB}$ family of transcription factors plays a crucial role in many inflammatory diseases, such as arthritis, asthma, atherosclerosis, and Alzheimer's disease (44). The expression of these transcription factors is central in the expression of many inflammatory cytokines, and the role NF- $\mathrm{KB}$ plays in inflammatory diseases probably results from defects in the regulatory mechanisms controlling its activation (35). In most cell types, NF- $\mathrm{BB}$ is sequestered in the cytoplasm in an inactive form through association with any of several IкB inhibitor proteins $(\mathrm{I} \kappa \mathrm{B} \alpha, \mathrm{I} \kappa \mathrm{B} \beta, \mathrm{I} \kappa \mathrm{B} \varepsilon, \mathrm{I} \kappa \mathrm{B} \gamma, \mathrm{p} 105$, p100, and $\mathrm{Bcl}-3)$. In response to a wide array of stimuli, IкB is phosphorylated, ubiquinated, and degraded, allowing NF-кB to translocate to the nucleus where it can regulate gene expression (45). In this report, electrophoretic mobility shift assays revealed bands of greater intensity indicating a greater amount of NF- $\mathrm{KB}$ factors bound to the recognition motif in the CCL2 promoter region in the nuclear extracts of T cells from mammary tumor-bearing mice. The probed nuclear proteins from tumor bearers' $\mathrm{T}$ cells migrated faster in the gel compared to those of normal $\mathrm{T}$ cells, signifying a lower molecular weight of the transcription factor complex with the tumor burden. Differential binding of nuclear proteins could affect gene expression. Supershift assays using anti-p50, -65, and c-Rel antibodies indicated that RelA (p65) binds to the CCL2 promoter in only the normal $\mathrm{T}$ cells and that c-Rel plays a larger role in the binding to the promoter in these cells compared to those of $\mathrm{T}$ cells from tumor bearers. The participation of these higher molecular weight transcription factors in the CCL2 promoter in normal T cells explains the retarded migration of nuclear extracts compared to those of tumor bearers. While the heterodimers p50-c-Rel were observed in $\mathrm{T}$ cells from normal and tumor bearers, the $\mathrm{T}$ cells from tumor bearers had higher levels of nuclear factors as indicated by darker bands. The predominant transcription factor complex involved in the NF- $\mathrm{NB}$ promoter in tumor bearers' $\mathrm{T}$ cells was $\mathrm{p} 50 / \mathrm{p} 50$ homodimers. The biological role of p50 homodimers is ambiguous. In some experimental systems, p50 homodimers function to enhance transcription (46), but in others, p50 acts as a repressor (47), binding $\mathrm{\kappa B}$ sites normally activated by p50/p65 heterodimers (46). However for transactivation, p50-c-Rel heterodimers are required. In our tumor model, both p50 homodimers and p50 -c-Rel heterodimers were functioning as activators of transcription of CCL2 in T lymphocytes.

The networks regulating the NF- $\mathrm{KB}$ activation are more complex than previously envisioned (48) and other signaling pathways have been reported in other cell types including neutrophils, eosinophils, and dendritic cells affecting effector functions $(12,49,50)$. We therefore investigated pathways upstream of NF-кB in GM-CSF-induced CCL2 secretion. Pharmacologic inhibitors were used to demonstrate the signaling pathways involved in the GM-CSF-induced secretion of CCL2. Our studies revealed significant decreases in CCL2 production by tumor bearers' $\mathrm{T}$ cells treated with wortmannin, TLCK, staurosporin, and PD98059, thus demonstrating a role for PI3 kinase, NF-кB, PKC and ERK1/ MAP kinase in the production of CCL2 by T cells. Our findings suggest that the signaling pathways in GM-CSFinduced CCL2 production in primary $\mathrm{T}$ lymphocytes from mammary tumor-bearing mice are mediated through shared pathways involving multiple kinases and $\mathrm{NF}-\kappa \mathrm{B}$ activation resulting in CCL2 gene transcription. This can have a significant impact on tumor growth and the immune response since we have previously shown that treatment of T lymphocytes with CCL 2 results in decreased interferon- $\gamma$ secretion. This may affect the overall immune response against the tumor.

\section{Acknowledgements}

We are grateful to Dr Diana M. Lopez for reviewing the manuscript and for her insightful comments. The excellent technical assistance of Mantley Dorsey Jr. is gratefully acknowledged. This study was supported by grant F02S-FAU1 from the Florida division of the American Cancer Society.

\section{References}

1. Locati M, Bonecchi R and Corsi MM: Chemokines and their receptors: roles in specific clinical conditions and measurement in the clinical laboratory. Am J Clin Pathol 123: S82-S95, 2005.

2. Matsushima K, Larsen CG, DuBois GC and Oppenheim JJ: Purification and characterization of a novel monocyte chemotactic and activating factor produced by a human myelomonocytic cell line. J Exp Med 169: 1485-1490, 1989.

3. Carr MW, Roth SJ, Luther E, Rose SS and Springer TA: Monocyte chemoattractant protein 1 acts as a T-lymphocyte chemoattractant. Proc Natl Acad Sci USA 91: 3652-3656, 1994.

4. Allavena P, Bianchi G, Zhou D, et al: Induction of natural killer cell migration by monocyte chemotactic protein-1, -2 and -3 . Eur J Immunol 24: 3233-3236, 1994.

5. Kuna P, Reddigari SR, Rucinski D, Oppenheim JJ and Kaplan AP: Monocyte chemotactic and activating factor is a potent histamine-releasing factor for human basophils. J Exp Med 175: 489-493, 1992.

6. Lopez DM, Handel-Fernandez ME, Cheng X, et al: Cytokine production by lymphoreticular cells from mammary tumorbearing mice: the role of tumor-derived factors. Anticancer Res 16: 3923-3929, 1996. 
7. Fu YX, Watson G, Jimenez JJ, Wang Y and Lopez DM: Expansion of immunoregulatory macrophages by granulocytemacrophage colony-stimulating factor derived from a murine mammary tumor. Cancer Res 50: 227-234, 1990.

8. Owen JL, Lopez DM, Grosso JF, et al: The expression of CCL2 by $\mathrm{T}$ lymphocytes of mammary tumor bearers: role of tumorderived factors. Cell Immunol 235: 122-135, 2005.

9. Brown AL, Peters M, D'Andrea RJ and Gonda TJ: Constitutive mutants of the GM-CSF receptor reveal multiple pathways leading to myeloid cell survival, proliferation, and granulocytemacrophage differentiation. Blood 103: 507-516, 2004.

10. Guthridge MA, Stomski FC, Thomas D, et al: Mechanism of activation of the GM-CSF, IL-3, and IL-5 family of receptors. Stem Cells 16: 301-313, 1998.

11. Lendemans S, Rani M, Selbach C, Kreuzfelder E, Schade FU and Flohe S: GM-CSF priming of human monocytes is dependent on ERK1/2 activation. J Endotoxin Res 12: 10-20, 2006.

12. Al-Shami A, Mahanna W and Naccache PH: Granulocytemacrophage colony-stimulating factor-activated signaling pathways in human neutrophils. Selective activation of Jak2, Stat3, and Stat5b. J Biol Chem 273: 1058-1063, 1998.

13. Suh HS, Kim MO and Lee SC: Inhibition of granulocytemacrophage colony-stimulating factor signaling and microglial proliferation by anti-CD45RO: role of Hck tyrosine kinase and phosphatidylinositol 3-kinase/Akt. J Immunol 174: 2712-2719, 2005.

14. Valdembri D, Serini G, Vacca A, Ribatti D and Bussolino F: In vivo activation of JAK2/STAT-3 pathway during angiogenesis induced by GM-CSF. FASEB J 16: 225-227, 2002.

15. Dijkers PF, van Dijk TB, de Groot RP, et al: Regulation and function of protein kinase B and MAP kinase activation by the IL-5/GM-CSF/IL-3 receptor. Oncogene 18: 3334-3342, 1999.

16. Martinez-Moczygemba M and Huston DP: Biology of common beta receptor-signaling cytokines: IL-3, IL-5, and GM-CSF. J Allergy Clin Immunol 112: 653-666, 2003.

17. Kato T and Kitagawa S: Regulation of neutrophil functions by proinflammatory cytokines. Int J Hematol 84: 205-209, 2006.

18. Martin T, Cardarelli PM, Parry GC, Felts KA and Cobb RR: Cytokine induction of monocyte chemoattractant protein-1 gene expression in human endothelial cells depends on the cooperative action of NF-kappa B and AP-1. Eur J Immunol 27: 1091-1097, 1997.

19. May MJ and Ghosh S: Signal transduction through NF-kappa B. Immunol Today 19: 80-88, 1998

20. Karin M: How NF-kappaB is activated: the role of the IkappaB kinase (IKK) complex. Oncogene 18: 6867-6874, 1999.

21. Pahl HL: Activators and target genes of Rel/NF-kappaB transcription factors. Oncogene 18: 6853-6866, 1999.

22. Medina D and DeOme KB: Response of hyperplastic alveolar nodule outgrowth-line D1 to mammary tumor virus, noduleinducing virus, and prolonged hormonal stimulation acting singlely and in combination. J Natl Cancer Inst 42: 303-310,1969.

23. Julius MH, Simpson E and Herzenberg LA: A rapid method for the isolation of functional thymus-derived murine lymphocytes. Eur J Immunol 3: 645-649, 1973.

24. Chitnis S, Mondal D and Agrawal KC: Zidovudine (AZT) treatment suppresses granulocyte-monocyte colony-stimulating factor receptor type alpha (GM-CSFR alpha) gene expression in murine bone marrow cells. Life Sci 71: 967-978, 2002.

25. Muta H, Boise LH, Fang L and Podack ER: CD30 signals integrate expression of cytotoxic effector molecules, lymphocyte trafficking signals, and signals for proliferation and apoptosis. J Immunol 165: 5105-5111, 2000.

26. Schreiber E, Matthias P, Muller MM and Schaffner W: Rapid detection of octamer binding proteins with 'mini-extracts', prepared from a small number of cells. Nucleic Acids Res 17: 6419,1989

27. Peterson GL: A simplification of the protein assay method of Lowry et al which is more generally applicable. Anal Biochem 83: 346-356, 1977.

28. Lopez DM, Lopez-Cepero M, Watson GA, Ganju A, Sotomayor E and $\mathrm{Fu}$ YX: Modulation of the immune system by mammary tumor-derived factors. Cancer Invest 9: 643-653, 1991.

29. Charyulu VI and Lopez DM: Elevated GM-CSF levels in tumor bearing mice upregulate IL-6 production by B cells via a mechanism independent of TNF- $\alpha$. Int J Oncol 16: 161-167, 2000.

30. Proost P, Wuyts A, Opdenakker G and Van Damme J: Monocyte chemotactic proteins 1,2 and 3. In: Cytokines. Mire-Sluis AR and Thorpe R (eds). Academic Press, New York, p494, 1998 .
31. Hayashida K, Kitamura T, Gorman DM, Arai K, Yokota T and Miyajima A: Molecular cloning of a second subunit of the receptor for human granulocyte-macrophage colony-stimulating factor (GM-CSF): reconstitution of a high-affinity GM-CSF receptor. Proc Natl Acad Sci USA 87: 9655-9659, 1990.

32. Li Q, Withoff $\mathrm{S}$ and Verma IM: Inflammation-associated cancer: NF-kappaB is the lynchpin. Trends Immunol 26: 318-325, 2005.

33. Papa S, Zazzeroni F, Pham CG, Bubici C and Franzoso G: Linking JNK signaling to NF-kappaB: a key to survival. J Cell Sci 117: 5197-5208, 2004.

34. Schottelius AJ and Dinter H: Cytokines, NF-kappaB, microenvironment, intestinal inflammation and cancer. Cancer Treat Res 130: 67-87, 2006

35. Ueda A, Okuda K, Ohno S, et al: NF-kappa B and Sp1 regulate transcription of the human monocyte chemoattractant protein-1 gene. J Immunol 153: 2052-2063, 1994.

36. Collantes E, Valle Blazquez M, Mazorra V, Macho A, Aranda E and Munoz E: Nuclear factor-kappa B activity in T cells from patients with rheumatic diseases: a preliminary report. Ann Rheum Dis 57: 738-741, 1998.

37. Pikarsky E, Porat RM, Stein I, et al: NF-kappaB functions as a tumour promoter in inflammation-associated cancer. Nature 431: 461-466, 2004

38. Adib-Conquy M, Adrie C, Moine P, et al: NF-kappaB expression in mononuclear cells of patients with sepsis resembles that observed in lipopolysaccharide tolerance. Am J Respir Crit Care Med 162: 1877-1883, 2000.

39. Ghosh P, Sica A, Young HA, et al: Alterations in NF kappa $\mathrm{B} / \mathrm{Rel}$ family proteins in splenic T-cells from tumor-bearing mice and reversal following therapy. Cancer Res 54: 2969-2972, 1994.

40. Suzuki K, Hino M, Hato F, Tatsumi N and Kitagawa S Cytokine-specific activation of distinct mitogen-activated protein kinase subtype cascades in human neutrophils stimulated by granulocyte colony-stimulating factor, granulocytemacrophage colony-stimulating factor, and tumor necrosis factor-alpha. Blood 93: 341-349, 1999.

41. Guthridge MA, Barry EF, Felquer FA, et al: The phosphoserine-585-dependent pathway of the GM-CSF/IL-3/IL-5 receptors mediates hematopoietic cell survival through activation of NF-kappaB and induction of bcl-2. Blood 103: $820-827,2004$

42. Klein JB, Rane MJ, Scherzer JA, et al: Granulocytemacrophage colony-stimulating factor delays neutrophil constitutive apoptosis through phosphoinositide 3-kinase and extracellular signal-regulated kinase pathways. J Immunol 164: 4286-4291, 2000.

43. McDonald PP, Bald A and Cassatella MA: Activation of the NF-kappaB pathway by inflammatory stimuli in human neutrophils. Blood 89: 3421-3433, 1997.

44. Kumar A, Takada Y, Boriek AM and Aggarwal BB: Nuclear factor-kappaB: its role in health and disease. J Mol Med 82: 434-448, 2004

45. Epinat JC and Gilmore TD: Diverse agents act at multiple levels to inhibit the Rel/NF-kappaB signal transduction pathway. Oncogene 18: 6896-6909, 1999.

46. Kurland JF, Kodym R, Story MD, Spurgers KB, McDonnell TJ and Meyn RE: NF-kappaB1 (p50) homodimers contribute to transcription of the bcl-2 oncogene. J Biol Chem 276: 45380-45386, 2001.

47. Cao S, Zhang X, Edwards JP and Mosser DM: NF-kappaB1 (p50) homodimers differentially regulate pro- and antiinflammatory cytokines in macrophages. J Biol Chem 281 26041-26050, 2006

48. Hoffmann A, Natoli G and Ghosh G: Transcriptional regulation via the NF-kappaB signaling module. Oncogene 25: 6706-6716, 2006.

49. de Groot RP, Coffer PJ and Koenderman L: Regulation of proliferation, differentiation and survival by the IL-3/IL-5/GMCSF receptor family. Cell Signal 10: 619-628, 1998.

50. Jenkins BJ, Blake TJ and Gonda TJ: Saturation mutagenesis of the beta subunit of the human granulocyte-macrophage colonystimulating factor receptor shows clustering of constitutive mutations, activation of ERK MAP kinase and STAT pathways, and differential beta subunit tyrosine phosphorylation. Blood 92: 1989-2002, 1998 